\title{
STEM STUDENTS' ENGAGEMENT TO FOSTER INTERNATIONAL MARKETING THROUGH DIGITAL CONTENT
}

\author{
Vera Grāvīte \\ Rezekne Academy of Technologies, \\ Vidzeme University of Applied Sciences, Latvia \\ Iveta Putniņa \\ Rezekne Academy of Technologies, \\ Vidzeme University of Applied Sciences, Latvia
}

\begin{abstract}
This article aims to find the opportunities how to facilitate the interaction among students, university staff and future students in order to attract more and better students in the field of STEM by sharing students' digital content on social media. As a potential student group - generation $Z$ are already technology geeks, spend a lot of time on social media, know about the newest technologies and know how to use them it's crucial to provide content that can impress them as future STEM students with technologies, opportunities, skilled staff and successful alumni.

This paper includes the transformation and adjustment of the main aim for each stage, functions, digital content categories and subcategories, as well the interaction level among students, university staff and future students.
\end{abstract}

Keywords: international marketing, digital marketing, generation marketing, STEM marketing, content marketing.

\section{Introduction}

Declining enrolment figures, reduction in funding, and global competition are seen as the main reasons why universities worldwide are increasingly investing in marketing activities (Whisman, 2011), at the same time focusing on the industries where there is a lack of qualified specialists. The Eurostat data about digital economy (Eurostat, 2019) show that the problem with the employment of STEM (Science, Technology, Engineering, and Mathematics) (www.ed.gov) specialists exists not only in Latvia where 700 specialists graduate every year, but at least 3000 are needed, but also in other European countries (Eurostat, 2019).

Universities need to think about proper marketing activities for potential students to help to improve the situation in universities and the industry. Taking into account the profile of being a small university in Northern Europe, Vidzeme University of Applied Sciences (ViA) saw a potential in testing new approaches 
for STEM students' international marketing activities, which was also part of the project “Next Generation Micro Cities of Europe” (www.va.lv/en).

In $2019 \mathrm{ViA}$ had a round of discussions for its marketing strategy on recruiting students in the information technology field (STEM). In order to attract ambitious, self-determined, active and interested students, the involved experts agreed that it was necessary to look for integrated solutions in cooperation with professional partners, schools and international partners, as well as use the internal diversity of study fields to strengthen the uniqueness of one study program (ViA strategy 2020, 3-7). The missing link in designing the university marketing ecosystem was a detailed insight in how to involve STEM students in co-creation of international marketing digital content and how to embed it as a part of orchestrated marketing network. Customer engagement is one out of ten types of in Doblin Innovation framework, which is used by Deloitte (Deloitte, 2019, 23). Following the method of resonating innovation cycles (Project proposal: Engaged and Entrepreneurial European University as Driver for European Smart and Sustainable Regions (E3UDES ${ }^{2}$ ), 2020, 6), the group of researchers worked on "dynamic experiments based on a process of inquiry" (Harward Business Review, 2019, 137). During 2019 and 2020, ViA marketing and researchers' team defined and designed the STEM students' engagement concept.

Many research papers have shown the importance of a well-planned online marketing plan for universities (A. Duesterhaus, M. Duesterhaus, 2014, 169-183). According to the research, the digital marketing has changed the world, and the higher education sector is no exception (Palmer, 2013: 333-344). The use of social media for attracting students has become a reality for European institutions (Asderaki, Maragos, 2012, 498-510). Although practitioners' reports based on the impact of social media marketing are still studied every year, academic evidence revealed its positive results already 10 years ago (Steinfield et al., 2009).

The aim of the paper is to find the opportunities how to facilitate the interaction among students, university staff and future students in order to attract more and better students in the field of STEM by sharing students' digital content on social media. A literature review, focus group discussions, surveys, content analysis, and a benchmarking exercise involving a similar university provided the main findings for this publication.

\section{Literature Review Digital Marketing and Higher Education Institution}

Digital marketing is an umbrella term for the marketing of products or services using digital technologies, mainly on the Internet, but it also includes mobile phones, display advertising, and any other digital medium (Sathya, 2017). The development of information and communication technologies in recent 
decades has significantly influenced the marketing activities and plans of universities. Tools and possibilities open up unprecedented opportunities, but at the same time present challenges in finding the best and most appropriate solution to attract and retain potential students, especially when other institutions use similar methods, and other approaches are time-consuming or expensive (Dwivedi, 2020).

Everybody is looking for the best way to attract students using social media, artificial intelligence and other technologies and marketing solutions that help to deliver digital content to prospective students, but do not help to create one (Pew Research Center, 2020). Social media has changed the way communication and engagement take place, including the possibility of influencing each other through their use (Labrecque, 2014, 43-50). Using social media, content can be shared by anyone, regardless of their social status, popularity or number of readers, such as posting stories, sharing thoughts live, and more (Labrecque, 2014, 37-50). Some people become more interesting to society than others and over time influence what other people think, want to wear, and so on.

Smith $(2018,35)$ asserts that "the key to making a difference through social media is being proactive about how you present yourself, thereby, influencing the information people find" (Vitelar, 2019, 263-268). Finding the way how to use social media as a higher education institution brand will allow reaching more people, saving money and getting feedback, although the social media platforms used for personal branding are various (Vanderford, 2017, 119-138).

Due to three big structural changes in the economy: 1) rollback of regulations; 2) blurring of separation between product and services; 3) development of technology, the ecosystems, especially designed ones, are on the rise (Harward Business Review, 2019, 130). On the other hand, the number of stakeholders for universities has increased significantly, and in the annual conference of the European Association of International Education in 2019 Bert van der Zwaan from Utrecht University (the Netherlands) defined 18 forces that will affect university strategy in 2040 (EAIE, 2019, 5). The traditional organizational approach of the university cannot ensure such level of communication and marketing activities in order to take into account the needs of all the stakeholders. However, the proposed solution of "focusing on the competition between digitally enabled designed ecosystems that span traditional industry boundaries and offer complex and customizable product-services bundles" might work not only in the business environment, but also in higher education (Harward Business Review, 2019, 132). According to Deloitte Innovation Survey 2019, being part of an ecosystem is crucial to shorten innovation cycles and remain in touch with trends (Deloitte, 2019, 23). There is already an example from Finland - Finnish Ministry of Education and Culture and Laurea University of Applied Sciences on the ongoing research on co-creation 
orchestration as an evidence-based governance model enhancing the ecosystem's value in co-creation, knowledge transfer, and business development (Äyväri, 2019, 388). The European research and innovation policy has emphasized the engagement of citizens, local communities and civil society at the core of the new European Research Area to achieve greater societal impact and increased trust in science (European Commission, 2020, 16). The ecosystems as orchestrated networks (Harward Business Review, 2019, 130) are a new way of governance not only at the policy and organisational level, but also at the individual department level within an organisation.

For a particular group of people - Generation Z, a professional image and brand is an important part not only for them as individuals, but also looking at organisation, products, services, etc. they might use (Harris, Rae, 2011). Generation Z members are content creators (Madden, 2017). They use social media and instant Internet connectivity for accessing resources (IPSOS MORI, 2018, 105). They more often use mobile phones, tablets and other devices and also are a big part of social media such as Facebook, Instagram, Tik Tok, Youtube, etc. (IPSOS MORI, 2018, 78), and that is the way they receive most of the information (Zinātnes komunikācijas project, SKDS 2019, Civitta study) mostly through a video format (IPSOS MORI, 2018, 78).

\section{STEM Education for Generation Z}

Generation $\mathrm{Z}$ is coming of the age as the first talents of Generation $\mathrm{Z}$ join the workforce. The existing literature describes Generation $\mathrm{Z}$ as a cohort of individuals born between 1995 and 2009, currently between the ages of 10-24 years. However, there are slightly different approaches regarding the years encompassing this younger generation: Tapscott (2008) frames this generation between 1998 - 2008, Dimock (2019), Madden (2017) consider anyone born between 1995 and 2009 a Post-Millennial or Generation Z member. Most members belonging to this generation are still in their teens, the older ones just reaching the age of 24 years (Vitelar, 2019, 260-261).

Generation Z members have grown up with instant global connectivity facilitated by smartphones, tablets, wearable devices, social media platforms and so forth (Madden, 2017). With the all the opportunities they have, Generation Zers are highly creative, constantly adaptive (Madden, 2017), and have a highly marketable digital mindset (Lyons, etc., 2017).

They deeply understand digital transformation. Today's students have a deep understanding of how technology can transform the way we work and live, and colleges and universities have the challenge of maintaining relevance among students who are increasingly more reliant on technology as a communication source, (Kusumawati, 2019, 1-10) also thinking about studies. There are many 
factors that have an impact on the subject choices that students make. Palmer, Burke, and Aubusson (2017) found out that students ranked enjoyment, interest and ability, and the perceived need in their future study or career plans as the most important factors in both choosing and rejecting subjects. They considered advice from teachers, parents, or peers to be relatively less important. According to several studies, enhancing students' enjoyment, interest, and perceptions of their ability in science, and their attitude towards it, as well as increasing student perceptions of the value of science in a future career may result in more students studying science at school (Palmer et al., 2017, 645-662).

But the Internet and the widespread use of smart phones has also had a major impact on learning styles. The members of Generation $\mathrm{Z}$ have grown up in a world that is always connected. The answer to any question is just a Google search away. According to a study by Seemiller and Grace (2017), Generation Z students like independent, self-paced learning with opportunities for collaboration as needed. They see their instructor as a learning facilitator who helps them to develop relevant and practical skills. They may also need help to critically evaluate online sources and learn how to process large amounts of information (Moore, Jones etc., 2017, 111-126). All these needs affect the way how universities' lecturers should teach students and how marketing specialists should promote study opportunities, thinking about a student-centred approach.

\section{Student-centred Approach in Marketing}

The student-centred approach is based on the hypothesis that students who are given the freedom to explore areas based on their personal interests, and who are accompanied in their striving for solutions by a supportive, understanding facilitator not only achieve higher academic results, but also experience an increase in personal values, such as flexibility, self-confidence and social skills (Renata, Holzinger, 2002, 160-162). The main strategy of marketing is the same - bring together different parties (students, staff, etc.) in order to jointly produce a mutually valued outcome (Prahalad, Ramaswamy, 2014, 5-14).

This approach, also known as experiential learning, requires specific personal attitudes on the side of the instructor who takes over the role of a facilitator. These attitudes are highly transparent, open communication, positive regard towards students and search for deep understanding (Rogers, 1983).

In such a complex system (Kurtz and Snowden, 2003, 462), in order for the co-design process to function and develop in an optimal and fluid way, it is useful to identify what can stop or - on the contrary - stimulate the motivation of individuals to engage as co-designers or at least contributors in a process over which they seem to have no control (Dupont, etc., 2019, 1-53). 
Grāvìte \& Putniņa, 2021. Stem Students' Engagement to Foster International Marketing Through Digital Content

Koschatzky said that "firms which do not cooperate and which do not exchange knowledge reduce their knowledge base on a long-term basis and lose the ability to enter into exchange relations with other firms and organizations" (Koschatzky, 2001, 6), in case of universities and colleges it can be related to the work with students and staff.

The main thing is to find a balance between the student's wishes and opportunities to create content and the university's need for content that could be used for marketing. Innovation requires creativity and a certain amount of risktaking, so the results are uncertain and unpredictable, making it impossible to draft precise terms and clauses of a contract in advance.

\section{Research Design}

For the purposes of designing a digitally enabled international marketing ecosystem, part of the research was implemented via a dynamic experiment. The main aim of this experiment was to define interaction principles, the aim and functions for STEM students' engagement, as well as the main categories and subcategories of digital content. Based on the findings from the literature and the resonating innovations cycles methodology, a combination of different scientific methods was used for the co-creation of the STEM students' engagement concept. The resonating cycles describe the circular process, which connects strategy development, implementation, evaluation and the adaption of higher education institutions strategy. Resonating innovation cycles (Figure1.) adapt successful innovation methods to the specific needs. These maturity spirals start with small, manageable, easily calculable, prototypical tasks and actions. While the analysis of errors and inadequate results serves as the basis for new ideas and concepts, the following steps are repeated with promising approaches: (1) share, pool, map, discuss and reflect on existing knowledge, experience and good practice, (2) prioritise missions, identify and define challenges, (3) co-ideate promising approaches, (4) co-create using human-centred design to develop and explore prototype solutions, (5) test and experiment within defined environments and frameworks, (6) evaluate: measure output, verify outcome, determine impact, (7) learn and improve: document new knowledge, reflect on new experience, collect good practice examples (Project proposal: Engaged and Entrepreneurial European University as Driver for European Smart and Sustainable Regions (E3 UDRES $)$, 2020, 6). 


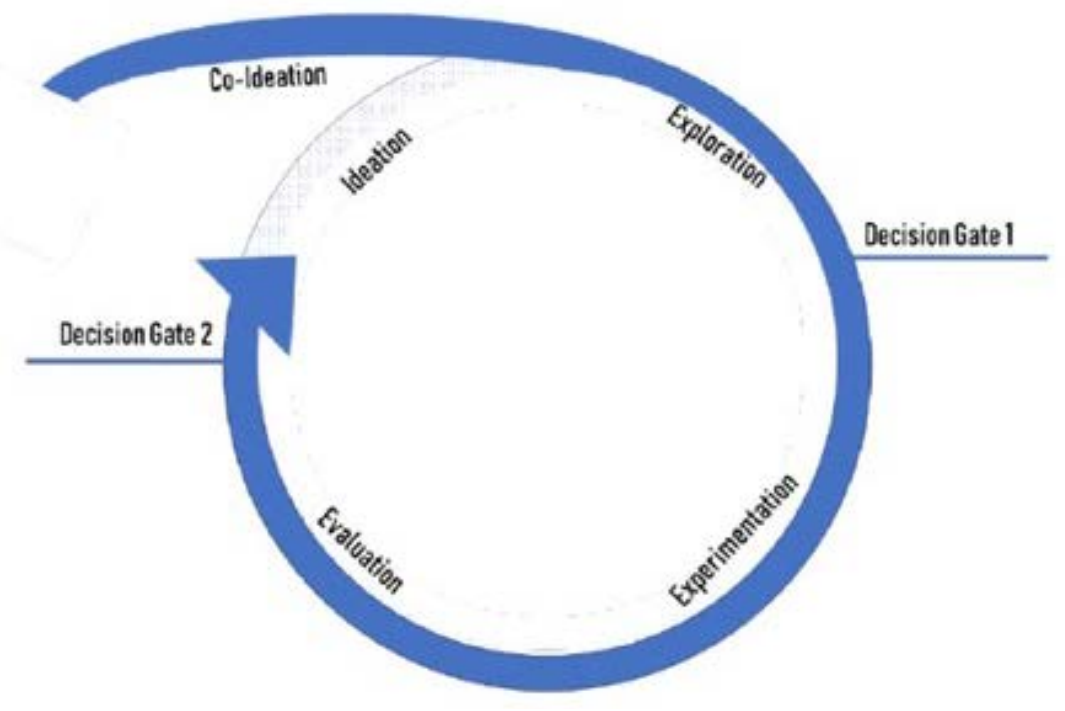

Figure 1 Resonating Innovation Cycles

(Project proposal: Engaged and Entrepreneurial European University as Driver for European Smart and Sustainable Regions (E²UDES²), 2020, 6)

The researchers' team selected various methods for each stage. To identify the background information for international marketing ecosystem at Stage 1, the following research methods were used:

1) literature studies about digital marketing in higher education institutions, Generation Z students, STEM students, designed ecosystems, and the student-centred approach;

2) the peer-consulting method on the uniqueness of information technology study program with 12 ViA Engineering Faculty teachers;

3) the focus group discussion with 7 STEM students who responded to the university invitation. The idea of the focus group was to talk about their experience in sharing information on social media, and find out what kind of platforms they use and if they would like to be part of the university marketing.

During Stage 2, after the first full round of STEM students' engagement in creating digital content, the experiment was evaluated using the following methods:

1) the analysis of questionnaires from 12 students who participated in Stage 2 and worked on creation of unique digital content (in total 15 students participated, 12 students submitted questionnaires);

2 ) the qualitative analysis of the created digital content - 30 videos provided the necessary data in order to adjust the defined functions, define and map categories and subcategories for connecting ViA STEM students and future local and international students; 
Grāvìte \& Putniņa, 2021. Stem Students' Engagement to Foster International Marketing Through Digital Content

3) the analysis of 60 first-year students' questionnaires on the opinion about the main factors influencing their decision on studies at ViA;

4) the benchmarking exercise with a similar activity at the project partner university: Ventspils University of Applied Sciences (Latvia) for comparing the results of the STEM students' digital content and the analysis of interaction level during the experiment.

\section{Discussion: STEM Students’ Engagement Concept (3 Stages)}

The goal of the experiment was to involve 15 STEM and media students who create digital content (photo, video, blogs, pools, etc.) and share them on their social media during spring 2020. The university provided the necessary equipment and editing software, regular consultations on technical questions for creating own digital content. Part of the experiment was influenced by the COVID-19 pandemic, and students had to look for solutions how to finish the tasks while observing social distancing.

Stage 1 - Starting point - UNIVERSITY - defining the initial framework for the students' engagement concept - what is there for the university?

Taking into account the university discussions on the marketing strategy and the need for a purpose of Generation $\mathrm{Z}$, the marketing team defined the main aim of the STEM students' engagement concept - what can you teach everyone while studying information technologies in ViA, Valmiera? Thus, showing why they have to study STEM in this university and in this micro-city.

The marketing team also defined the first set of functions of the students' digital content:

1) help others in their STEM subjects' studies;

2) give advice on how to solve everyday problems related to information technology field (for example, how to install antivirus);

3) provide a broader use of the acquired knowledge, thus improving the study results by sharing examples with peers and pupils;

4) show the benefits of the study program and profession.

In order to test the chosen approach with STEM students, the researchers organised a focus group with 7 STEM students and introduced the initial STEM students' engagement concept. The following drawbacks were identified on why this concept might not work:

1) students were puzzled as to what is expected from them;

2) they emphasized that too much effort will be needed to create such type of digital content;

3) they were not sure how to use the study course materials for the purposes outside courses; 
4) students were not ready to share this content on their social media (the most likely reasons were not enough confidence in the ability to create good digital content and resistance to use personal social media for promoting the university).

Following the results of the STEM students' focus group, several changes were made to the initial concept taking into account the student-centred approach.

Stage 2 - STUDENTS - adapting the STEM students' engagement concept - what is there for STEM students?

Using the student-centred approach, the marketing team made changes to the aim of the student digital content - create useful digital content, which introduces to the profession and creates the interest in STEM.

The revised functions of the student digital content were (starting with the least effort requiring to the most challenging):

1) introduce STEM students by posting their public presentations in the university or visiting schools in their social media;

2) provide insight into STEM studies and the specific terminology by interviewing STEM students;

3) share examples from the best STEM graduates' final thesis, successful projects, and well-evaluated practical training;

4) create unique digital content, which describes why you should study information technologies, what you should know before studies, why study information technologies, 10 things students should know;

5) encounter STEM stereotypes via live videos and podcasts;

6) create opinion leaders among ViA students - encourage and raise interest to share different type of information about their studies (study process, environment, lectures, professionals from the industry) via the following subcategories: innovative and applied methods; culture and affiliation; job opportunities; entertainment; weather; accommodation.

15 STEM and media students participated in Stage 2 during spring 2020 and created 30 digital content examples, which they shared in their social networks. 12 questionnaires from the participating students, the qualitative analysis of 30 videos, 60 questionnaires from the first-year students, and benchmarking with a similar university were used to evaluate Stage 2: measure output, verify outcome, and determine impact.

The following drawbacks were identified from the 12 questionnaires from 15 students who worked on the digital content:

1) it was challenging to come up with and create interesting and useful content;

2) adapting to the COVID-19 situation and limitations to use the university equipment and editing software; 
Grāvìte \& Putniņa, 2021. Stem Students' Engagement to Foster International Marketing Through Digital Content

3) too many materials with similar content (for example, time-lapse on studies, free time, sport);

4) students were still resistant to use private social networks for publishing the created content (several students created new profiles in order to post their materials instead of using the existing profiles);

5) there were no videos with advice for peers or future students or examples how to solve everyday problems related to information technologies.

The first positive results:

1) the first examples of STEM students' digital content were published, it had a wider audience than the interaction of average ViA posts (including after sharing the same content at the university's official social networks);

2) a greater credibility of students' published content than ViA content;

3) very good cooperation with students from communication study programs and the co-created digital content (for example, the communication student who interviews the information technology student).

Figure 2 summarizes the benefits of engaging in the creation of digital content, Figure 3 provides the insight in the main challenges during this activity, and Figure 4 provides the general evaluation from the students' point of view.

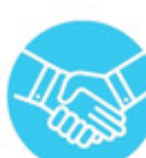

cooperation possibility with students from other study groups

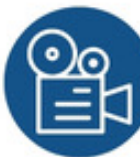

improved technical skills - editing and filming

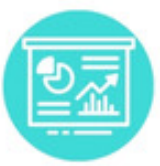

improved soft skills creative work, work in teams, time planning
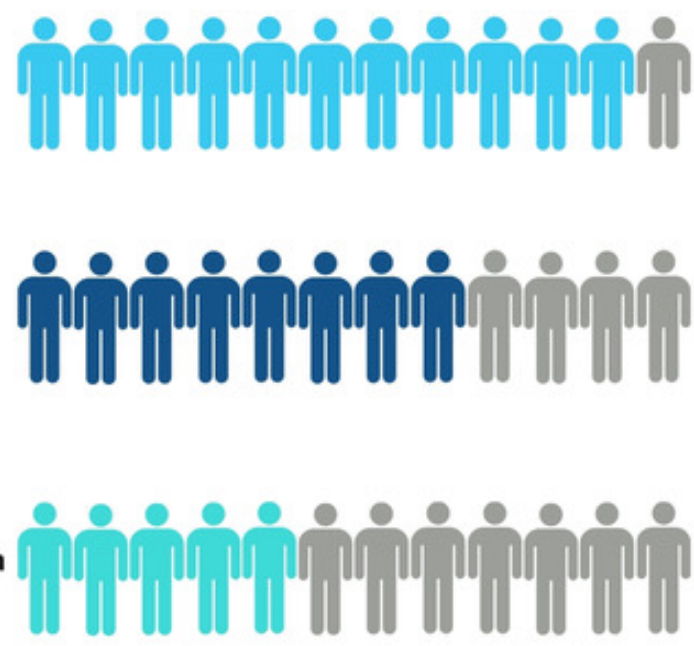

Figure 2 Benefits from the Participation in the STEM Students' Engagement Activity

(the number of students who mentioned the following benefits in their questionnaires from the total number of students who submitted the questionnaires; 15 students participated, 12 students submitted questionnaires) 

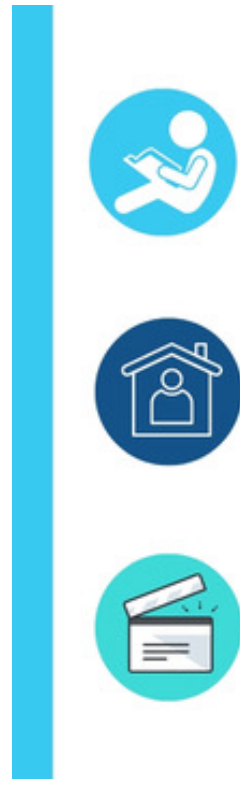

create a good story

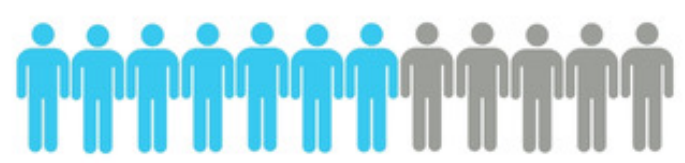

soft skills as time planning, creative skills, communication, working remotely during Covid-19

technical skills as editing, filming
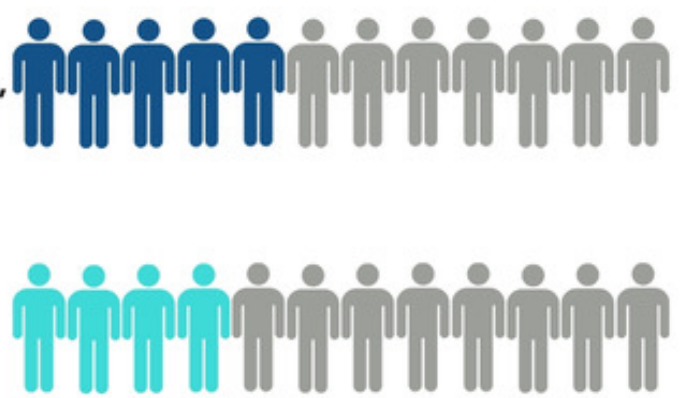

Figure 3 Identified Challenges during the Participation in the STEM Students'

Engagement activity (the number of students who mentioned the following challenges in their questionnaires from the total number of students who submitted the questionnaires;

15 students participated, 12 students submitted questionnaires)

general evaluation of the practical training in creating the digital content

personal progress in creating the content for social media

awareness of benefits from public communication in social media

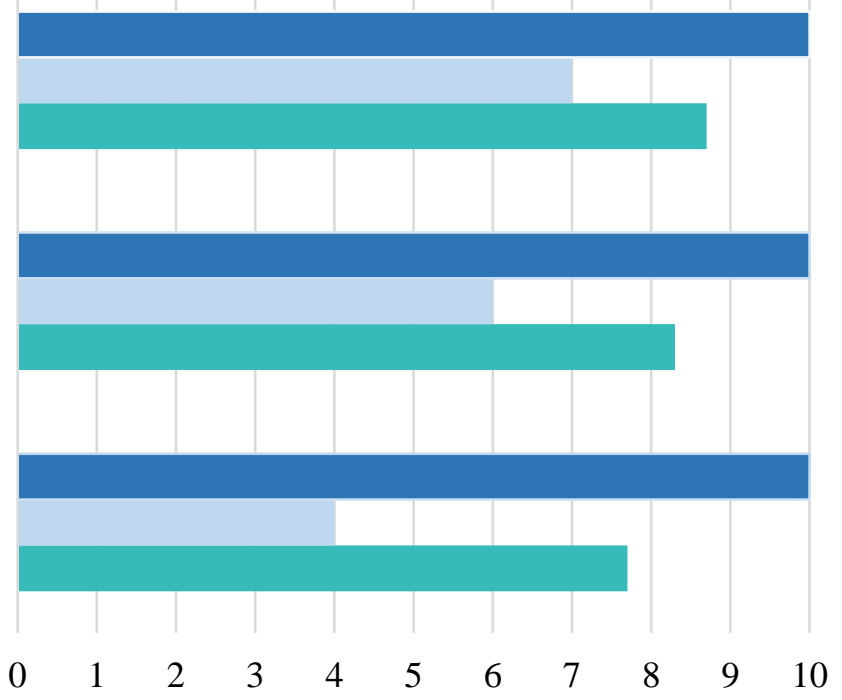

घ Highest evaluation $\square$ Lowest evaluation $\square$ Average evaluation

Figure 4 General Evaluation of the Participation in the STEM Students' Engagement Activity

Before Stage 2, the marketing team planned that the STEM students' digital content would address 6 functions and 6 subcategories of their studies. The 
Grāvìte \& Putniņa, 2021. Stem Students' Engagement to Foster International

Marketing Through Digital Content

researchers used real examples of STEM students' videos and their content to specify functions, categories and subcategories in order to facilitate the intended interaction from the university's point of view and the students' perspective (see Table 1).

Table 1 The Overview of Functions and Categories in Comparison: Planned Versus Actual Materials

\begin{tabular}{|c|c|c|c|}
\hline $\begin{array}{c}\text { Functions planned for } \\
\text { Stage } 2\end{array}$ & \begin{tabular}{|c|} 
Whether the \\
STEM \\
students' \\
digital content \\
represents this \\
function \\
\end{tabular} & Comments or examples & $\begin{array}{l}\text { Suggestions for the } \\
\text { next stage }\end{array}$ \\
\hline $\begin{array}{l}\text { Introduce STEM students by } \\
\text { posting their public } \\
\text { presentations in the } \\
\text { university or visiting schools } \\
\text { on their social media }\end{array}$ & No & $\begin{array}{l}\text { The function too general, } \\
\text { probably no added value } \\
\text { or the task was not } \\
\text { challenging enough for } \\
\text { the students }\end{array}$ & Cancel \\
\hline $\begin{array}{l}\text { Provide insight into STEM } \\
\text { studies and the specific } \\
\text { terminology by interviewing } \\
\text { STEM students }\end{array}$ & Yes & $\begin{array}{l}3 \text { videos - the content was } \\
\text { more related to study } \\
\text { opportunities in general, } \\
\text { free time activities, Val- } \\
\text { miera, sports possibilities; } \\
\text { few examples on the spe- } \\
\text { cifics of STEM studies. }\end{array}$ & $\begin{array}{l}\text { Rename as: get to } \\
\text { know STEM } \\
\text { students, their } \\
\text { reasons for choosing } \\
\text { studies, free time } \\
\text { activities, hometown, } \\
\text { Valmiera, etc. }\end{array}$ \\
\hline $\begin{array}{l}\text { Share examples from the } \\
\text { best STEM graduates' final } \\
\text { thesis, successful projects, } \\
\text { and well evaluated practical } \\
\text { training }\end{array}$ & No & $\begin{array}{l}\text { The students were first- } \\
\text { year students. They are } \\
\text { still on the way to their } \\
\text { first successful projects. }\end{array}$ & Needs to be modified \\
\hline $\begin{array}{l}\text { Create unique digital } \\
\text { content, which describes } \\
\text { why you should study } \\
\text { information technologies, } \\
\text { what you should know } \\
\text { before studies, why study } \\
\text { information technologies, } 10 \\
\text { things students should know }\end{array}$ & No & $\begin{array}{l}\text { Probably the topic was } \\
\text { too broad, difficult to re- } \\
\text { late to individual students } \\
\text { experience. However, } \\
\text { some answers were pro- } \\
\text { vided during the inter- } \\
\text { views with company } \\
\text { representatives. }\end{array}$ & Needs to be modified \\
\hline $\begin{array}{l}\text { Encounter STEM stereotypes } \\
\text { via live videos and podcasts }\end{array}$ & yes & $\begin{array}{l}9 \text { videos with the inter- } \\
\text { views of different com- } \\
\text { pany representatives } \\
\text { discussing the everyday } \\
\text { operations of the compa- } \\
\text { ny, history, development, } \\
\text { work conditions and op- } \\
\text { portunities for employees, } \\
\text { competences needed, } \\
\text { advice for students }\end{array}$ & $\begin{array}{l}\text { Rename: get to know } \\
\text { industry } \\
\text { representatives, their } \\
\text { companies, industry } \\
\text { development trends, } \\
\text { work opportunities, } \\
\text { skills needed and } \\
\text { advice for students }\end{array}$ \\
\hline
\end{tabular}


Proceedings of the International Scientific Conference. Volume I, May $28^{\text {th }}-29^{\text {th }}$, 2021. 163-183

\begin{tabular}{|c|c|c|c|}
\hline $\begin{array}{l}\text { Create opinion leaders } \\
\text { among ViA students - } \\
\text { encourage and raise interest } \\
\text { to share different type of } \\
\text { information on their studies } \\
\text { (study process, environment, } \\
\text { lectures, professionals from } \\
\text { the industry) via following } \\
\text { subcategories: }\end{array}$ & $\begin{array}{c}\text { Some } \\
\text { examples }\end{array}$ & $\begin{array}{l}\text { Probably the topica was } \\
\text { too broad, difficult to } \\
\text { relate to individual } \\
\text { students experience. } \\
\text { However, many examples } \\
\text { were provided in the } \\
\text { specific categories. }\end{array}$ & $\begin{array}{l}\text { Rename using } \\
\text { specific categories } \\
\text { and subcategories. }\end{array}$ \\
\hline $\begin{array}{l}\text { innovative and applied } \\
\text { methods }\end{array}$ & yes & $\begin{array}{l}1 \text { video - one day as a } \\
\text { video game }\end{array}$ & - \\
\hline culture and affiliation & yes & $\begin{array}{l}11 \text { videos on the typical } \\
\text { day for students during } \\
\text { the pandemic and how } \\
\text { they adapted }\end{array}$ & - \\
\hline job opportunities & yes & $\begin{array}{l}\text { See the description of the } \\
\text { company representatives' } \\
\text { videos }\end{array}$ & - \\
\hline entertainment & $\begin{array}{c}\text { Some } \\
\text { examples }\end{array}$ & $\begin{array}{l}\text { Due to the COVID-19 } \\
\text { pandemic, only examples } \\
\text { related to time outdoors }\end{array}$ & - \\
\hline weather & yes & $\begin{array}{l}9 \text { videos on the weather } \\
\text { and nature in the area } \\
\text { where students live }\end{array}$ & - \\
\hline accommodation & $\begin{array}{c}\text { Some } \\
\text { examples }\end{array}$ & $\begin{array}{l}\text { Due to the COVID-19 } \\
\text { pandemic, video } \\
\text { examples are more related } \\
\text { to home accommodation } \\
\text { in different cities in the } \\
\text { region }\end{array}$ & - \\
\hline- & $\begin{array}{c}\text { New } \\
\text { subcategory: } \\
\text { everyday life } \\
\end{array}$ & $\begin{array}{l}6 \text { videos on the everyday } \\
\text { life after studies }\end{array}$ & - \\
\hline- & $\begin{array}{c}\text { New } \\
\text { subcategory: } \\
\text { STEM student } \\
\text { in an unusual } \\
\text { setting } \\
\end{array}$ & $\begin{array}{l}\text { videos with } \\
\text { entertainment elements }\end{array}$ & - \\
\hline
\end{tabular}

In order to find out what are the missing content elements, a further detailed insight was performed by analysing 60 questionnaires of the first-year students on the factors they found important for choosing studies and the STEM students' content they found the most attractive. The students were provided with 34 factors to consider how they influenced their decision on studies by ranking those factors from 5 (highest impact) to 1 (lowest impact). The top ranked factors were: 1) received the scholarship for studies; 2) STEM specialists are demanded in the job market, have good career opportunities and a well-paid job; 3) there are 
possibilities to receive the scholarship; 4) the study programme is unique and I am interested in this field. The top ten factors included also: the high reputation of the university and education of high quality; professional and not academic studies; positive recommendations and feedback from friends and relatives; modern and well-equipped university and facilities; good location; integration of social and technical studies. There were two factors that the students did not address in their digital content: 1) information on scholarships and study costs; 2) showing examples of the study programme uniqueness.

The next step was to identify and map different categories and subcategories, which were represented in the digital content. The overview is available in Figure 5. It summarizes the development of functions, categories and subcategories during the several stages: 1) categories and subcategories, which were identified in the STEM students' digital content; (4 functions, 10 categories, 18 subcategories); 2) important factors for futures students (2 functions, 3 categories, 13 subcategories); 3) frequently addressed categories and subcategories, which were identified in the benchmarking exercise (1 function, 2 categories, 12 subcategories).

The benchmarking exercise involving a similar activity at the project partner university Ventspils University of Applied Sciences showed several differences in how the STEM students' engagement concept was implemented. The total number of digital materials was much higher in Ventspils, however, those examples were shorter and covered fewer content categories. The functions of Ventspils students' digital content slightly differed from ViA students' content, however, the mapping of categories and subcategories provided new topics to be included in Stage 3. As a result, one more function was added to the STEM students' engagement concept and 2 categories, 12 subcategories.

Stage 3 - FUTURE STUDENTS - adapting the students' engagement concept - what is there for future STEM students?

Concluding the evaluation phase of the first resonating innovation cycle, the researchers propose the co-created STEM students' engagement concept for Stage 3 and the next cycle.

The aim - to generate interest in STEM subjects.

The following functions worked well during Stage 2 and should be used for the next stage:

1) get to know STEM students;

2) get to know STEM industry representatives;

3) get to know weather and nature in the region;

4) get to know creative and funny side of STEM students;

Two more functions were added as they address the missing most important factors for future students:

5) inform on scholarships and study costs; 
6) show examples of study programme uniqueness;

And one function was added as it was frequently addressed in Ventspils students' digital content and could contribute to the aim of the Stage 3:

7) get to know STEM teachers and professors.

The overview of functions, categories and subcategories for the STEM students' engagement concept is presented in Figure 5. The final mapping is the result from the different stages of evaluation and justification to the specific function and category: 1) represents categories and subcategories in STEM students' digital content from Stage 2; 2) represents categories and subcategories from the analysis of future students' opinion; 3) represents categories and subcategories frequently addressed in Ventspils STEM students' digital content.

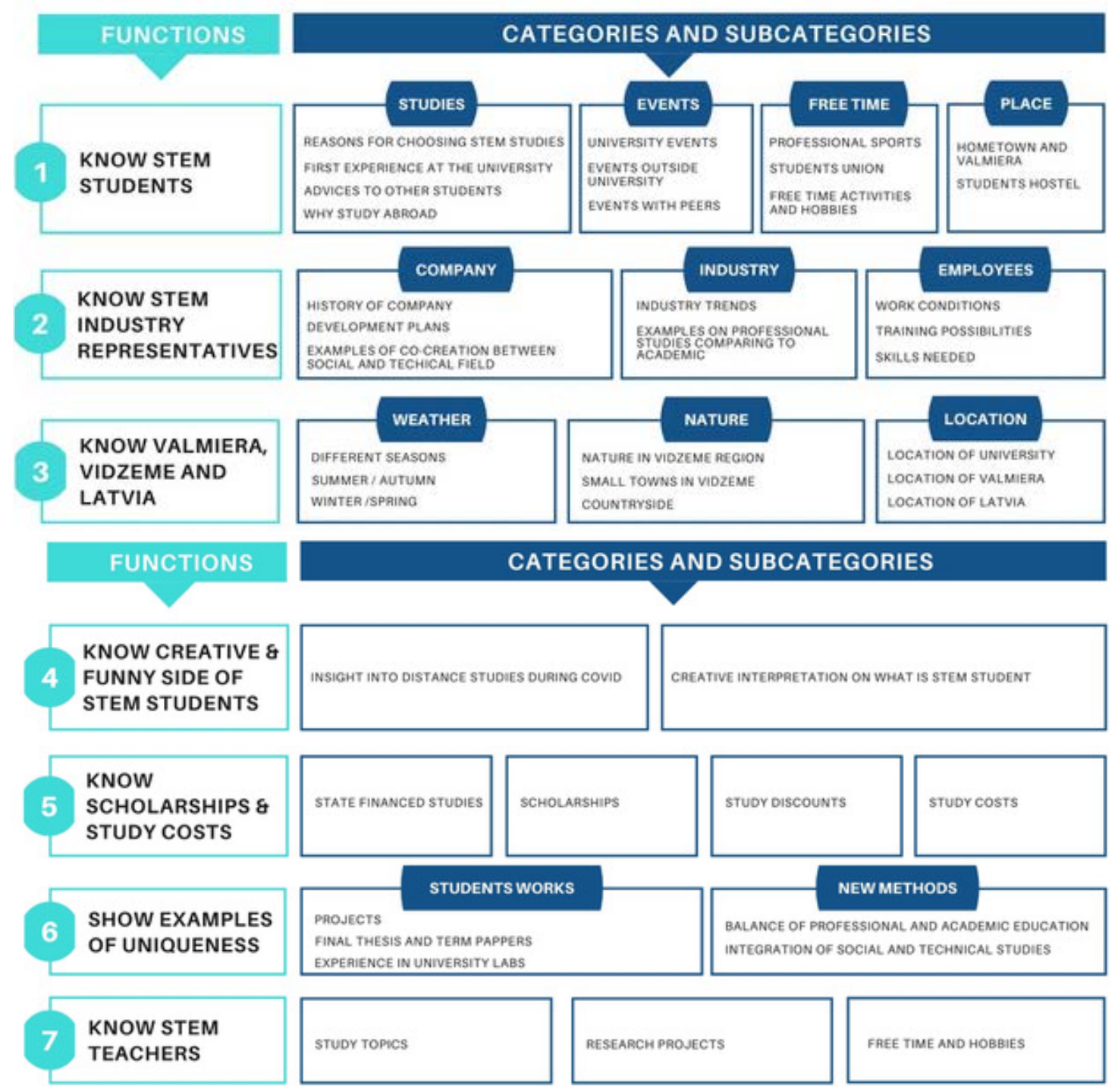

Figure 5 Overview of Functions, Categories and Subcategories of the STEM Students' Engagement Concept 
Grāvìte \& Putniņa, 2021. Stem Students' Engagement to Foster International Marketing Through Digital Content

\section{Results}

The researchers summarized and provided a broader insight in the results from the co-creation and transformation of the STEM students' engagement concept during the two stages and provided the suggestions for the next - Stage 3. This includes the transformation and adjustment of the main aim for each stage, functions, digital content categories and subcategories, as well the interaction level among students, university staff and future students.

The experiment revealed the transformation how universities can implement the transition from the university-centred approach to the student-centred approach in creation of marketing digital content, what drawbacks can be expected and what solutions might be introduced. The Figure 6 summarizes the transformation of the main aim for the STEM students' engagement concept. In Stage 1, the main aim was defined based on the interest from the university and the marketing point of view, which was too confusing and not understandable for students, therefore it was adjusted for Stage 2 according to the results of the students' focus groups. However, after the evaluation of Stage 2 and the analysis of future students' needs, the researchers' team transformed the aim of Stage 3 with the focus on the interest in STEM subjects.

\section{Transformation of Aim}

Transformation from the university-centred approach to the studentcentered approach in STEM students' engagement concept

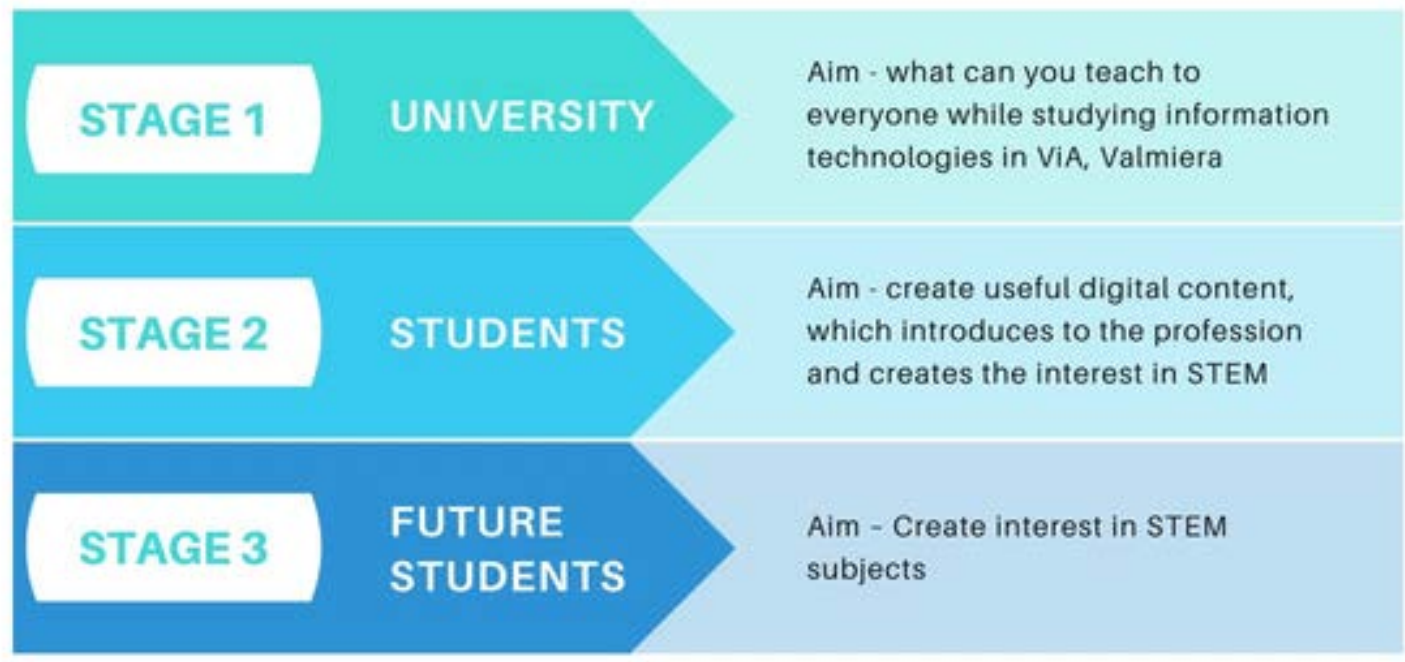

Figure 6 Transformation from the University-centred Approach to the Student-centred Approach in the STEM Students' Engagement Concept

The researchers' team used a similar approach to the adjustment and transformation of functions for the STEM students' digital content. The marketing team defined the functions for Stage 1, which were revised after discussions with 
students and adjusted after evaluating Stage 2. Figure 7 summarizes the changes in the functions of digital content in all three stages.

\section{Transformation of functions}

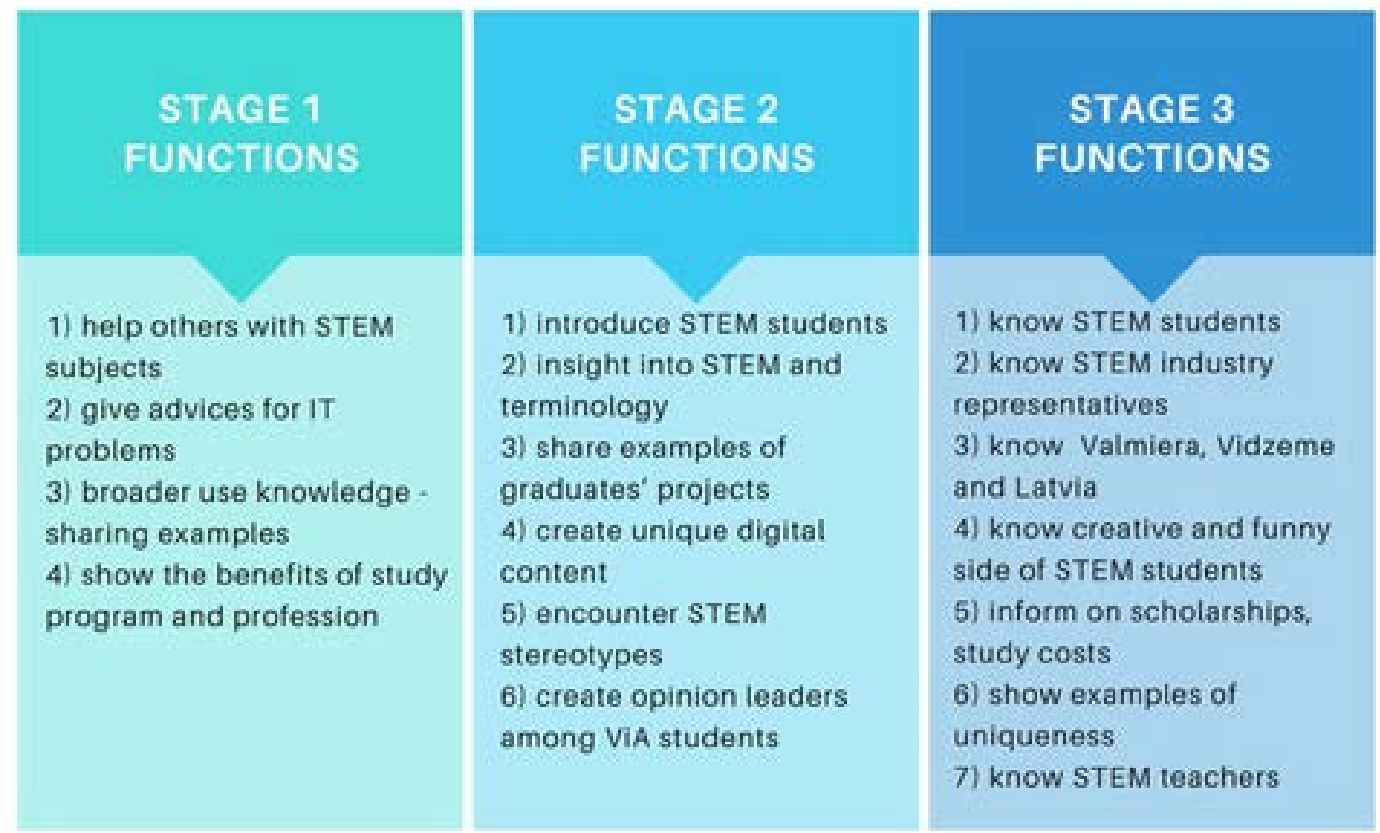

Figure 7 Transformation of Functions from More General to Better Structured and Justified Functions

However, creating an international marketing ecosystem requires a step-bystep development and cannot be set up during a short period of time. There is also a need for many individual adjustments according to every university's culture and mindset as the interaction level among involved parties increases at every stage. Figure 8 shows the development of interaction in ViA international marketing ecosystem through various stages. There were 3 main parties: STEM students, media students and industry representatives who cooperated in the process of creating digital content during Stage 2. The digital content after this stage represented 4 functions, 10 categories and 18 subcategories. More detailed analysis of future students' expectations provided the necessary information for first adjustments: 2 more functions, 3 categories and 13 subcategories were identified as a significant digital content. In order to spot more opportunities, the benchmarking exercise helped to extend and justify the functions and categories by adding one more function, 2 categories and 12 subcategories. In total 7 functions, 15 categories and 43 subcategories were mapped for Stage 3. This will require the interaction of five involved parties at various settings and teams: STEM students, media students, industry representatives, teachers and future students. 
Grāvìte \& Putniņa, 2021. Stem Students' Engagement to Foster International Marketing Through Digital Content

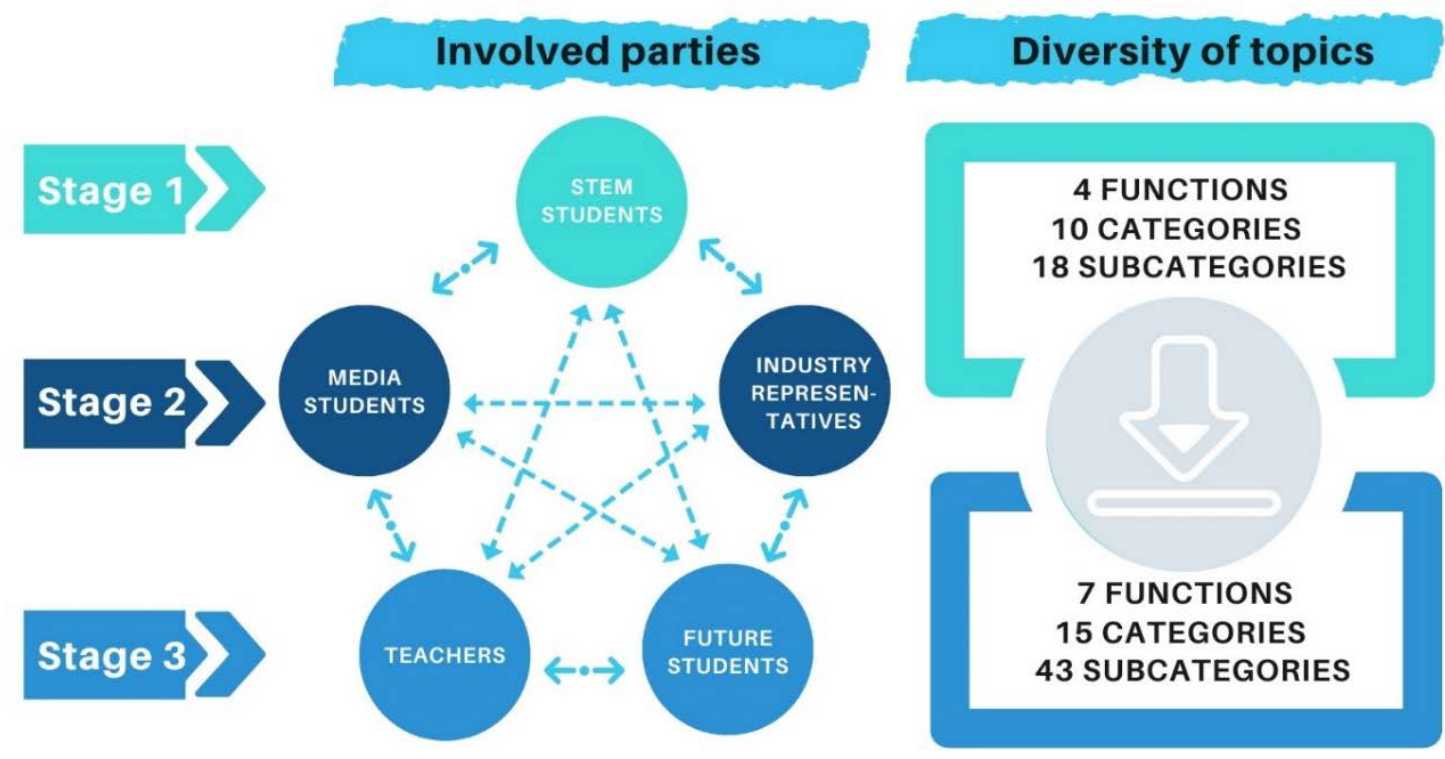

Figure 8 Interaction Level among Involved Parties in the Process of Creating Digital Content during Various Stages

\section{Conclusions}

This paper describes the interaction level which is needed for STEM students' engagement to foster international marketing. The three stages clearly indicate moving from a more general aim and functions to more specific, better structured and justified functions that are easier to perceive not only by the existing students, but also by future students. All aspects such as the target audience, social media platform, message and the common concept are an important part to make the syntax between a content maker and a receiver. As a potential student group - Generation $\mathrm{Z}$ are already technology geeks, spend a lot of time on social media, know about the newest technologies and know how to use them, it is crucial to provide content that can impress them as future STEM students with technologies, opportunities, skilled staff and successful alumni.

The used method and the combination of recent theoretical findings and a dynamic experiment provided the needed flexibility for moving from the university-centred to the student-centred approach. At the same time, this approach showed the areas where the framework is necessary in order to focus the message of STEM students' digital content and relate it more to future students' needs.

There is a growing demand for matching needs and personalization opportunities - finding and choosing what you are interested in or what is needed in a particular situation, ignoring everything that is not relevant or interesting or unnecessarily delays time. It is important for this generation that education is 
student-centred (focused on student opportunities, not university achievements), and at the same time it must demonstrate a link with global trends and events. The most evident limitation of this study is that a relatively small number of respondents (university students) was involved in the research and more representatives of other technical study programs should be engaged for a broader view. Also the shortage of foreign students may have affected the current results. Expanding the number of respondents, and using these combined methods of research should be extremely useful for broadening the knowledge in this field and finding the way to attract more foreign and local students to STEM study fields.

The findings of this research is the first step in an ongoing study on the generation marketing and expanding student digital content in the marketing ecosystem. The research will continue until 2021 and will look into introducing digital tools in supporting the marketing ecosystem.

\section{Acknowledgements}

The authors are thankful for the financial support from Urban Innovation Actions Program (European Commission) within the project "Next Generation Microcities of Europe" (Nr.UIA03-250) and Vidzeme University of Applied Sciences (Latvia). This research would not be possible without the inspiring team of the project "Next Generation Microcities of Europe" who were involved in several stages of the project.

\section{References}

Asderaki, F., Maragos, D. (2012). The internationalization of higher education: The added value of the European portals and social media pages for the national and the institutional internationalization strategies. International Conference proceedings, Information Communication Technologies in Education, 13, 498-510.

Äyväri, A., Hirvikoski, T., Uitto, H. (2019). Identifying Living Lab orchestrators' individuallevel skills. OpenLivingLab Days 2019 Conference Proceedings, European Network of Living Labs, 388.

Beane, M. (2019). UC Santa Barbara, Learning to work with Intelligent Machines, 140 - 148. Harward Business Review, September-October. Retrieved from: https://eurlex.europa.eu/legal-content/EN/TXT/?uri=COM\%3A2020\%3A628\%3AFIN

Deloitte Insights. (2019). Innovation in Europe. A Deloitte survey on European companies and how digital technologies can strategically enhance innovation, 23. Retrieved from: https://www2.deloitte.com/content/dam/insights/us/articles/DE_897_Innovation-inEurope/DI_Innovation-In-Europe.pdf

Dimock, M. (2019). Defining generations: Where Millennials end and Generation Z begins. Pew Research Center. Retrieved from: https://www.pewresearch.org/facttank/2019/01/17/where-millennials-endand-generation-z-begins/. 
Grāvìte \& Putniņa, 2021. Stem Students' Engagement to Foster International

Marketing Through Digital Content

Doblin. (2019). Ten types of innovation, the innovation practice of Monitor Deloitte within Deloitte Consulting. Retrieved from: https://www.doblin.com/ten-types.

Duesterhaus, A. P., Duesterhaus, M. (2014). Attributes of successful university brands in the U.S.A. Journal of Brand Strategy, 3(2), 169-183.

Dupont, L., Mastelic, J., Nyffeler, N., Latrille, S., Saulliet, E. (2019). Living lab as a support to trust for co-creation of value: application to the consumer energy market, 1-53. Retrieved from: Living lab as a support to trust for co-creation of value: application to the consumer energy market [1] | Cairn.info

Dwivedi, Y., Ismagliova, E. et al. (2020). Setting the future of digital and social media marketing research: Perspectives and research propositions. DOI: https://doi.org/ 10.1016/j.ijinfomgt.2020.102168

European Association of International Education (EAIE). Annual conference 2019, session "Higher Education in 2040: changing concepts", Presentation from Bert van der Zwaan (Utrecht University, the Netherlands).

European Commission. (2020). Communication from the Commission to the European Parliament, the Council, the European Economic and Social Committee and the Committee of the Regions. A new ERA for Research and Innovation, Brussels.

Eurostat data. (2019). ICT specialists in employment. Retrieved from: ICT specialists in employment - Statistics Explained (europa.eu)

Harris, L., Rae, A. (2011). Building a personal brand through social networking. Journal of Business Strategy, 32(5), 14-21. DOI:10.1108/02756661111165435

IPSOS MORI. (2018). Beyond Binary. The Lives and Choices of Generation Z, 78-105. Retrieved from: https://www.ipsos.com/it-it/beyond-binary-lives-and-choicesgeneration-z.

Koschatzky, K. (2001). Networks in Innovation Research and Innovation Policy - An Introduction, 1. DOI: 10.1007/978-3-642-57610-2_1

Kurtz, C.F., Snowden, D.J. (2003). The new dynamics of strategy: Sense-making in a complex and complicated world, 31 (4), 462. DOI: 10.1109/EMR.2003.24944

Kusumawati, A. (2019). Impact of Digital Marketing on Student Decision-Making Process of Higher Education Institution: A Case of Indonesia, 2-10. DOI: 10.5171/2019.267057

Labrecque, L. (2014). Fostering Consumer-Brand Relationships in Social Media Environments: The Role of Parasocial Interaction, 28 (2). DOI: 10.1016/j.intmar.2013.12.003

Labrecque, L.I., Markos, E., Milne, G.R. (2011). Online Personal Branding: Processes, Challenges, and Implications. Journal of Interactive Marketing, 25(1), 37-55. DOI:10.1016/j.intmar.2010.09.002

Lyons, M., LaVelle, K., Smith, D. (2017). Gen Z Rising. Accenture. Retrieved from: https://www.accenture.com/us-en/insight-gen-z-rising.

Madden, C. (2017). Hello Gen Z: Engaging the Generation of Post-Millennials. Sydney: Hello Clarity.

Moore, K, Jones, C, Frazier, R.C. (2017). Engineering Education For Generation Z, 111-126. Retrieved from: Microsoft Word - 3-8705 Moore.docx

NATO Strategic Communications Centre of Excellence. (2017). Strategic Communications / Insights from the Commercial Sector, 1-61.

Ozkan, M. (2017). Generation Z - The Global Market's New Consumers - And Their Consumption Habits: Generation $Z$ Consumption Scale, 5(1) 150-157. DOI: 10.26417/ejms.v5i1.p150-157

Palmer, T. A., Burke, P. F., Aubusson, P. (2017). Why school students choose and reject science: A study of the factors that students consider when selecting subjects. 
International Journal of Science Education, 39(6), 645-662. Retrieved from https://www.tandfonline.com/doi/abs/10.1080/09500693.2017.1299949

Palmer, S. (2013) Characterisation of the use of Twitter by Australian universities. Journal of Higher Education Policy and Management, 35(4), 333-344.

Prahalad, R. (2014). CO-CREATION EXPERIENCES: THE NEXT PRACTICE IN VALUE CREATION, 5-14. Retrieved from: 20015_ftp (icesi.edu.co)

Project proposal. (2020). Engaged and Entrepreneurial European University as Driver for European Smart and Sustainable Regions ( $\left.E^{3} U D R E S^{2}\right)$.

Renata, M.P., Holzinger, A. (2002). Student-Centered Teaching Meets New Media: Concept and Case Study, 160-162. Retrieved from: (10) (PDF) Student-Centered Teaching Meets New Media: Concept and Case Study (researchgate.net)

Rogers, C. R. (1983). Freedom to Learn for the 80's. New York: Charles E. Merrill Publishing Company, A Bell \& Howell Company.

Sathya, P. (2017). 'A Study on Digital Marketing and its Impact'. International Journal of Science and Research (IJSR), Volume 6, Issues 2. Retrieved from: https://www.ijsr.net/archive/v6i2/ART2017664.pdf

Seemiller, C., Grace, M. (2017). Generation Z: Educating and Engaging the Next Generation of Students. DOI: https://doi.org/10.1002/abc.21293

Smith, D. (2018). Social Media and Personal Branding. In Smith, D. (Ed.), 27-46 Growing Your Library Career with Social Media 1st Ed. Kidlington: Chandos Publishing. DOI:10.1016/b978-0-08-102411-9.00003-0

Steinfield, C., DiMicco, J., Ellison, N., \& Lampe, C. (2009). C\&T 2009, PA. USA: Pennsylvania State University.

Thomas, W., Malnight, (IDM), Buche, I. (IDM), Dhanaraj, C. (2019). (Temple University). Strategy: Put Purpose at the Core of Your Startegy, 70- 79. Harward Business Review, September-October. Retrieved from: https://eur-lex.europa.eu/legal-content/EN/ TXT/?uri=COM\%3A2020\%3A628\%3AFIN

Topscott, D. (2008). Grown Up Digital: How the Net Generation is Changing Your World, $1-368$.

U.S. Department of Education. (n.d.). Retrieved from: Science, Technology, Engineering, and Math, including Computer Science | U.S. Department of Education

Vanderford, N.L. (2017). The “Me Brand”. In Evans, T., Lundsteen, N., \& Vanderford, N. (Eds.), Research. A Career Guide for Scientists, (119-138). London: Academic Press. DOI:10.1016/b978-0-12-804297-7.00011-2

Vidzeme University of Applied Sciences. (n.d.). Webpage. Retrieved from: Next Generation Micro Cities of Europe | Vidzemes Augstskola (va.lv)

Vidzemes Augstskolas paaudžu mārketinga stratēgija. (2020). IT studentu piesaistei Ziemel̦eiropas mikropilsētā Valmierā, 1-27

Vitelar, A. (2019). Like Me: Generation Z and the Use of Social Media for Personal Branding, 259-266. DOI: 10.25019/MDKE/7.2.07

Vogels, E.A., Anderson, J. (2020). The innovations these experts predict by 2030. Retrieved from: The innovations these experts predict by 2030 | Pew Research Center.

Whisman, R. (2011). An academic enterprise approach to higher education branding. Retrieved from: http://www.brandedus.net/ThoughtLeadersConference.pdf. 